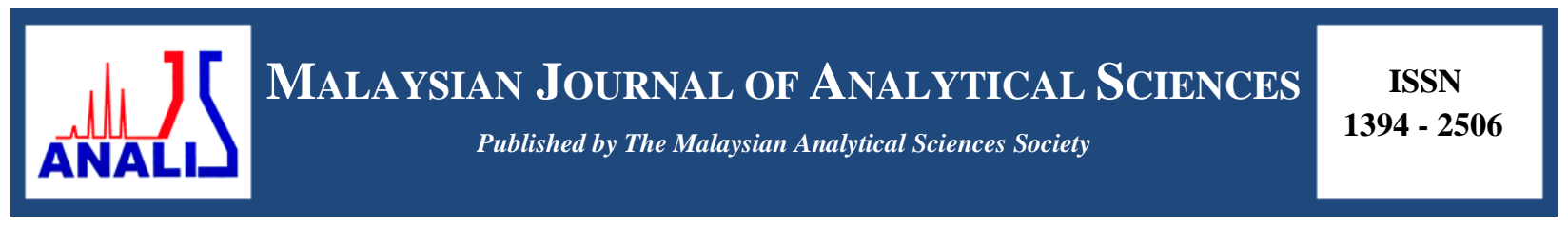

\title{
CHITOSAN-BASED ADSORBENTS FOR THE REMOVAL OF METAL IONS FROM AQUEOUS SOLUTIONS
}

\author{
(Bahan Penjerap Berasaskan Kitosan untuk Penyingkiran Ion Logam dari Larutan Akueus) \\ Zetty Azalea Sutirman ${ }^{1}$, Mohd Marsin Sanagi ${ }^{1,2 *}$, Khairil Juhanni Abd Karim ${ }^{1}$, Ahmedy Abu Naim ${ }^{1}$, \\ Wan Aini Wan Ibrahim ${ }^{1,2}$ \\ ${ }^{1}$ Department of Chemistry, Faculty of Science \\ ${ }^{2}$ Centre for Sustainable Nanomaterials, Ibnu Sina Institute for Scientific and Industrial Research \\ Universiti Teknologi Malaysia, 81310 UTM Johor Bahru, Johor, Malaysia \\ *Corresponding author: marsin@kimia.fs.utm.my
}

Received: 16 April 2017; Accepted: 7 March 2018

\begin{abstract}
Wastewater containing heavy metal ions is one of the most serious environmental concerns. Exposure to elevated levels of heavy metals can adversely affect water resources, endangering the ecosystems and human health. Among the various treatment technologies, adsorption using biopolymer seems a promising alternative method. Chitosan is a natural polymer produced from chitin with excellent properties such as biocompatibility, biodegradability and non-toxicity. Moreover, chitosan is known as an effective sorbent due to the presence of amino and hydroxyl groups in its molecules which can serve as attachment sites towards metal ions. Recently, chitosan derivatives as metal ion sorbents have gained considerable attention. These derivatives are prepared by either physical or chemical modifications or both in order to improve chitosan properties in adsorption. This paper discusses recent developments in the modifications of chitosan and the application of the derived materials in the removal of metal ions from aqueous solutions. The mechanisms of adsorption, metal sorption capacities, effect of $\mathrm{pH}$, isotherm and kinetic models are also described.
\end{abstract}

Keywords: chitosan, modification, sorption, metal ions

\begin{abstract}
Abstrak
Air sisa yang mengandungi logam berat merupakan salah satu isu alam sekitar yang serius. Pendedahan yang tidak terkawal kepada logam berat boleh menyebabkan kesan negatif terhadap sumber air, membahayakan ekosistem dan kesihatan manusia. Di antara pelbagai teknologi rawatan, penjerapan menggunakan biopolimer menunjukkan kaedah alternatif yang menjaminkan. Kitosan ialah polimer semula jadi yang dihasilkan daripada kitin dengan ciri-ciri seperti biokompatibiliti, biopenguraian dan bukan toksik. Tambahan pula, kitosan dikenali sebagai penjerap yang efektif kerana mempunyai kumpulan amina dan hidrosil dalam molekulnya yang bertindak sebagai tapak penghubung terhadap ion logam. Baru-baru ini, derivatif kitosan sebagai penjerap ion logam telah menerima perhatian yang luas. Derivatif-derivatif ini dihasilkan sama ada melalui pengubahsuaian fizikal atau kimia atau kedua-duanya untuk menambah baik ciri-ciri kitosan dalam penjerapan. Kertas ini membincangkan pengembangan yang terbaru dalam pengubahsuaian kitosan serta aplikasi daripada bahan derivatif dalam penyingkiran ion logam dari larutan akues. Mekanisma penjerapan, kapasiti penjerapan logam, kesan $\mathrm{pH}$, model dan kinetik juga diterangkan.
\end{abstract}

Kata kunci: kitosan, pengubahsuaian, penjerapan, ion logam

\section{Introduction}

Heavy metals such as cadmium $(\mathrm{Cd})$, mercury $(\mathrm{Hg})$, lead $(\mathrm{Pb})$, zinc $(\mathrm{Zn})$, arsenic $(\mathrm{As})$, nickel $(\mathrm{Ni})$ and chromium 


\section{Zetty Azalea et al: CHITOSAN-BASED ADSORBENTS FOR THE REMOVAL OF METAL IONS FROM AQUEOUS SOLUTIONS}

(Cr) are elements with atomic density of at least five times the specific gravity of water [1]. They are also known as trace elements due to their presence at low concentrations $(<1000 \mathrm{ppm})$ in environmental matrices. In fact, some of them have been recognized as essential nutrients for organisms (i.e. $\mathrm{Cu}$ and $\mathrm{Zn}$ ).

Even though heavy metals are natural components of the Earth's crust, most of environmental pollution and human exposure to heavy metals are caused by various anthropogenic activities such as military, industrial and agricultural processes and waste disposal. Heavy metals are also released to the ecosystem through natural processes like weathering of rocks and volcanic eruptions [2,3]. Most heavy metals are highly toxic to living organisms especially when their concentrations exceed the allowable limits in the ecosystem. These pollutants are non-biodegradable and can be absorbed by marine life. Once high concentrations of heavy metals enter the food chain, they tend to accumulate in living tissues and thus, dysfunction the system of the human bodies [4]. Hence, it is important to decontaminate or minimize these heavy metals from water sources in the interest of public health and the environment.

Up to now, various treatment methods have been developed to remove heavy metals, which include chemical precipitation, solvent extraction, ion exchange, evaporation, reverse osmosis, electrolysis and adsorption. However, most of these methods tend to show some economical and technical disadvantages [5]. For example, chemical precipitation has been widely used to remove dyes or heavy metals from inorganic effluent by increasing the $\mathrm{pH}$ of the solution to convert the soluble substances into an insoluble form. Even though the process is simple, it generates a large quantity of sludge which requires further treatment and high cost. Chemical precipitation is also not effective to remove trace level of pollutants from aqueous solutions. Meanwhile, in ion exchange method, the resin, either synthetic or natural solid, exchanges its cations with the unwanted substance in the wastewater. The problem is drawn when the ion exchanger is quickly polluted and thus, reducing the exchange capacity. In addition, this method usually consumes high capital and operational costs. Coagulation-flocculation has been capable of removing pollutants from solution, but the process can destabilize colloidal particles by adding a chemical agent (coagulant) which results in sedimentation [6,7]. Adsorption is established as the most effective method for water decontamination applications and analytical separation purposes. It offers advantages over the other options such as simplicity in terms of design and operation, uses less chemicals, requires low initial costs and can remove different types of pollutants $[4,8]$.

Chitosan, an amino polysaccharide produced from chitin are found naturally in some fungi. It is the most versatile biopolymer for a broad range of applications due to its biocompatibility, biodegradability and antibacterial property. Furthermore, this material is regarded as an ideal adsorbent. The presence of $-\mathrm{NH}_{2}$ and $-\mathrm{OH}$ groups on the polymeric backbone can serve as chelating and reaction sites [9].

Several methods have been employed to modify chitosan either physically or chemically to enhance adsorption capacity. Crosslinking is one of the common modifications performed on chitosan mainly to prevent its dissolution in acidic media [10]. This technique involves the formation of covalent bonds between two polymer chains by using bifunctional reagents containing reactive end groups that react with functional groups of chitosan (i.e. $\mathrm{NH}_{2}$ ). Therefore, it must be taken into account that crosslinking can reduce the adsorption capacity as it diminishes the number of free amino on chitosan, but this loss is worth to increase the stability of the polymer [11].

Another important modification is graft copolymerization. This approach has gained considerable interest among researchers and has become a vital technique in polymer chemistry. Grafting reaction provides various molecular designs leading to novel types of hybrid materials, which are composed of bio- and synthetic-polymers [12]. Chitosan has two types of reactive groups; hydroxyl and amine groups for grafting to occur. Different functional groups have been successfully grafted onto chitosan by covalent bond onto the chitosan backbone.

Several reviews on chitosan modifications have been reported particularly on metal ions removal from water of wastewater [10,13-16]. Other works on chitosan and its derivatives not limited to metal sorption have also been reviewed [17-21]. However, to the best of our knowledge, no detail review has been reported on different modifications of chitosan such as beading, crosslinking and grafting and their adsorption potential for various metal ions. In this paper, we present updated relevant information on the current modifications techniques employed on 
chitosan to enhance its properties in metal ions adsorption. The adsorption performances of chitosan-based adsorbents are also compared.

\section{Chitosan}

Chitosan, a main derivative of chitin, can be prepared by deacetylation of chitin under alkaline conditions (Figure 1). It was first discovered by Professor C. Rouget in 1859. Chitosan only occurs naturally in some fungi such as Mucor rouxii and Choanephora cucurbitarum. This polysaccharide is mainly composed of a linear of $\beta(1 \rightarrow 4)$ linked 2-amino-2-deoxy- $\beta$-D-glucopyranose. Since complete deacetylation of chitin is practically impossible, the molar ratio of $N$-acetyl-2-amino-2-deoxy-D-glucose (GlcNAc) is often expressed as a degree of $N$-acetylation (DA), which defines the average number of GlcNAc units per 100 monomers. Meanwhile, the deacetylation degree (DD) is used for 2-amino-2-deoxy-D-glucose $(\mathrm{GlcN})$ residue [22].
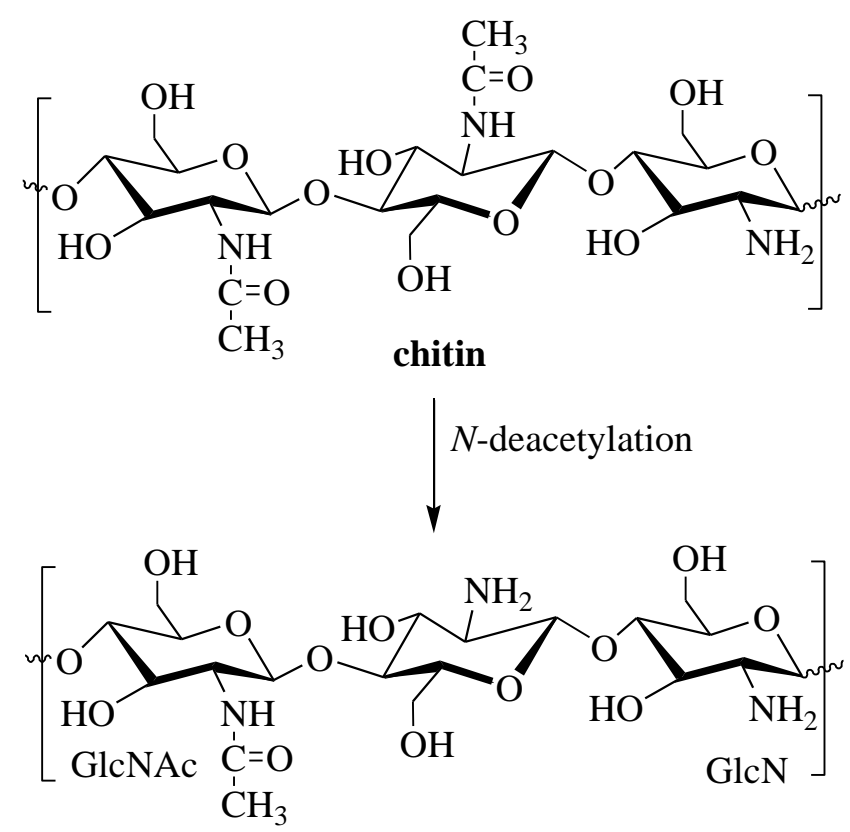

chitosan

Figure 1. Chemical structures of chitin and chitosan

Chitosan is named by the content of DD in the polymer. The DD for commercial chitosan is usually $70-95 \%$. Some researchers believe that chitosan is built up of at least $50 \%$ DD and soluble in aqueous acidic media [23, 24]. The solubility of chitosan occurs when the amino group, $-\mathrm{NH}_{2}$ on the $\mathrm{GlcN}$ repeated unit is protonated, converting the polysaccharide to polyelectrolyte $\left(\mathrm{pK}_{\mathrm{a}}=6.5\right)$. However, an exact nomenclature with respect to DD ratio between chitin and chitosan has not been clearly defined because it may vary depending on the production process, natural source and other factors [22].

The effectiveness of chitosan and its derivatives to interact with metal ions from aqueous solution has been studied by many workers. It is important to note that the adsorption capacities of these adsorbents depend on the experiment conditions such as $\mathrm{pH}$, initial concentration, contact time, adsorbent dosage, presence of competitive ions, etc.

\section{Modified chitosan}

Although chitosan shows a great potential as sorbent, it has severe drawbacks that restrict its application in water treatment and purification. Chitosan is commonly available in powder or flake form as the end product in the production process. It has crystallized structure due to strong inter- and intra-molecular hydrogen bonding in the 


\section{Zetty Azalea et al: CHITOSAN-BASED ADSORBENTS FOR THE REMOVAL OF METAL IONS FROM AQUEOUS SOLUTIONS}

structure, presents poor acid resistance and low porosity. In view of these limitations, raw chitosan is not suitable to be used in adsorption process without further modifications [25].

Modification of chitosan in adsorption study has two main goals. The first goal is to increase the chemical stability of the polymer in wide $\mathrm{pH}$-range aqueous media. The second goal is to improve the sorption performance such as sorption capacity and pollutant selectivity [13]. The modification of chitosan can be carried out by either physical or chemical techniques or both.

\section{Physical modification}

The selection of physical modification of chitosan depends mainly on the system configuration to be used for applications. In this manner, several techniques have been employed to mold chitosan into different morphologies such as powder, microspheres, hydrogels, membranes and fibers [26].

Solid chitosan can be obtained when chitosan in acidic aqueous solution is mixed with alkali. This method is usually used to prepare membranes, fibers and foremost, spherical gel beads of different sizes and porosities. Adarsh and Madhu [27] have prepared the beads by spraying chitosan solution into a precipitation bath containing $1 \mathrm{M} \mathrm{NaOH}$. In order to obtain membrane, chitosan solution was spread on a petri dish and dried. The membranes were then immersed in $\mathrm{NaOH}$ solution for neutralization [28]. Chitosan membrane or film can also be fabricated by the solvent evaporation method.

Furthermore, porous three-dimensional sponges can be prepared by freeze-drying. In this method, chitosan solutions or gels are frozen followed by lyophilization. The porosity and morphology of the material produced depends on the chitosan molecular weight and on the composition and concentration of the starting solution, and most importantly on the freezing temperature and freezing rate [29].

\section{Chemical modification}

Chitosan bears a large number of free hydroxyl and amino groups distributed along the backbone, which are an ideal candidate for chemical modification. The main aim of modifying chitosan is to vary properties such as solubility, water sorbency, adsorptive capability and thermal resistance. Chemical modification, however, would not change the fundamental skeleton of chitosan, yet affords a wide range of derivatives with desired properties for specific use and applications in various areas mainly of pharmaceutical, biomedical and biotechnological fields [10]. Derivatization by incorporating functional groups to chitosan may involve the $-\mathrm{NH}_{2}$ group at the C-2 position (specific reactions) or - OH groups at the $\mathrm{C}-3$ and $\mathrm{C}-6$ positions (non-specific reactions) [30].

Preparation of new chitosan-based materials may include impregnation, crosslinking, graft polymerization and composite formation [18]. The use of chitosan in relatively low $\mathrm{pH}$ solution is not feasible because it tends to form gel or dissolve. Thus, one way to overcome this problem is by inducing crosslinking on chitosan. Crosslinking agents or crosslinkers are generally bifunctional compounds with various forms such as straight chains, branch chains and rings. These crosslinking agents are classified upon their nature and interaction with biopolymer (i.e. chemical or physical crosslinking). Chemical crosslinking occurs when the crosslinker forms intermolecular covalent bond between the polymer chains. The reaction often involves the $-\mathrm{NH}_{2}$ and $-\mathrm{OH}$ functional groups on the biopolymer. Chemical crosslinking is commonly accomplished using crosslinker such as glutaraldehyde, epichlorohydrin, ethylene glycol diglycidyl ether, genepin, glyoxal, cylclodextrins, etc. [10,31]. Meanwhile, physical crosslinking results from non-covalent linkages between polymer chains. The reaction is weaker than chemical crosslinking since it relates to physical attractive forces such as ionic interaction, hydrophobic and hydrogen bonding. Pentasodium tripolyphosphate and calcium chloride are the two established examples of physical crosslinker. In a general way, crosslinking decreases the adsorption capacity slightly because amine groups of chitosan, which is known to be the main sites for target analytes, are usually bound with the crosslink agent to form a stable covalent bond (i.e. imine group).

Grafting copolymerization is another common way to improve adsorption capacity and increase chelating or complexation properties by introducing functional groups onto chitosan. During grafting reaction, side chains are covalently bonded to the main polymer backbone to give a branched structure copolymer. Until today, many 
research works have been carried out to synthesize graft copolymers by polymerization reaction of chitosan with monomer using free radical initiation. There are two main kinds of free radical initiating systems employed. The first type of initiation is called conventional or chemical initiation. In this system, the initiators used are usually thermal initiator and redox initiator. Meanwhile, the second type of initiation is free radical initiation by irradiation with either high energy (i.e. $\gamma$-ray) or low energy (i.e. microwave, UV light) [32].

\section{Chitosan beads and membranes}

Many studies have reported that the efficiency of adsorption strongly depends on the physicochemical properties of adsorbents including crystallinity, surface area, porosity and particle size. Therefore, chitosan flake or powder is not considered to be used as adsorbent due to its high crystallinity, resistance to mass transfer, low adsorption capacity and very low porosity. Small particle is also inappropriate for a fixed bed column system especially in industrial scale because they can increase their resistance to mass transfer rate, lead to clogging effect as well as hydrodynamic limitations [17]. Conversion of chitosan flake into bead has been reported to be essential as it allows the expansion of the polymer network, thus increasing access to internal sorption sites and enhancing diffusion mechanism.

Chitosan, in its native state, is characterized as a crystallized polymer. Since adsorption process usually occurs only at the amorphous region of the crystal, chitosan is usually subjected to physical modification by converting it into gel beads in order to reduce its crystallinity, thus enhancing the adsorption capacity. Cahyaningrum et al. reported the comparison between chitosan powder and chitosan beads for the removal of $\mathrm{Hg}$ (II) ions [33]. The results revealed that the adsorption capacity of the metallic ion by chitosan beads $\left(17.39 \times 10^{-4} \mathrm{~mol} \mathrm{~g}^{-1}\right)$ was much higher than that of chitosan powder $\left(7.20 \times 10^{-4} \mathrm{~mol} \mathrm{~g}^{-1}\right)$.

Wan Ngah et al. compared the adsorption capacity of chitosan flakes and beads as sorbents for removing $\mathrm{Pb}(\mathrm{II})$ ions from aqueous solution [34]. They found that the maximum adsorption capacity of chitosan beads was higher than that of chitosan flakes because the structure of the beads slightly changed because of reducing the crystallinity of chitosan. The adsorption of $\mathrm{Cu}(\mathrm{II})$ ions onto flake- and bead-type chitosan derived from shrimp was compared by $\mathrm{Wu}$ et al. [35]. The results showed that chitosan flakes possessed higher uptake for $\mathrm{Cu}(\mathrm{II})$ ions than that of chitosan flakes.

\section{Crosslinked chitosan}

As afore-mentioned, raw chitosan has a major limitation of being highly soluble in most dilute mineral and organic acid solutions by protonation of the amine groups. This makes it even more difficult to evaluate its application as sorbent in the treatment of industrial effluents. Crosslinking process has been found to be an effective method to reinforce chemical stability of chitosan under acidic conditions. Several common chemical crosslinking agents such as glutaraldehyde (GA), epichlorohydrin (EPC), triphosphate (TPP) and ethylene glycol diglycidyl ether (EDGE) have been used for this purpose. Results on metal ions adsorption onto crosslinked chitosan using different crosslinking agent are shown in Table 1. It is important to note that the adsorption capacities of the adsorbents cited in this paper depend on the experiment conditions such as $\mathrm{pH}$, initial concentration, contact time, adsorbent dosage, presence of competitive ions, etc.

Wan Ngah and Fatinathan successfully crosslinked chitosan beads with GA for removal of $\mathrm{Cu}(\mathrm{II})$ ions in aqueous solution [9]. The crosslinked chitosan was insoluble in acetic acid solution, showing crosslinking reaction enhanced the resistance of the polymer against acid. The researchers also investigated the effect of GA content in adsorption. An increase in the density of crosslinking lowered the adsorption capacity of chitosan because the number of amino groups that serve as binding sites for metal ions was reduced.

In another work, a batch experiment was carried out to study the adsorption of Fe(II) and $\mathrm{Fe}(\mathrm{III})$ ions by chitosan and crosslinked chitosan beads [43]. The chitosan beads were crosslinked with GA, EPC and EDGE in order to improve its chemical resistance and mechanical strength. The maximum adsorption capacity was in the sequence of chitosan $>$ chitosan-EPC $>$ chitosan-GA $>$ chitosan-EDGE. 


\section{Zetty Azalea et al: CHITOSAN-BASED ADSORBENTS FOR THE REMOVAL OF METAL IONS FROM AQUEOUS SOLUTIONS}

Table 1. Removal of different metal ions from aqueous solutions by crosslinked chitosan

\begin{tabular}{lccccc}
\hline Crosslinking Agent & $\begin{array}{c}\text { Metal } \\
\text { Ion }\end{array}$ & $\begin{array}{c}\boldsymbol{q}_{\text {max }} \\
\left(\mathbf{m g ~ g}^{-1}\right)\end{array}$ & $\mathbf{p H}$ & Isotherm & Reference \\
\hline TPP & $\mathrm{Cu}(\mathrm{II})$ & 200.0 & $4-5$ & $\mathrm{~L}$ & {$[36]$} \\
GA & $\mathrm{Pb}(\mathrm{II})$ & 24.2 & $5-7$ & $\mathrm{~L}$ & {$[37]$} \\
& $\mathrm{Cd}(\mathrm{II})$ & 23.9 & & $\mathrm{~L}$ & \\
GA crown ether & $\mathrm{Cd}(\mathrm{II})$ & - & 2 & - & {$[38]$} \\
& $\mathrm{Hg}(\mathrm{II})$ & 126.4 & 6 & - & {$[39]$} \\
& $\mathrm{Pb}(\mathrm{II})$ & 96.8 & 6 & - & \\
GA 2-aminopyridine glyoxal Schiff's base & $\mathrm{Pd}(\mathrm{II})$ & 166.7 & 8 & $\mathrm{~L}$ & {$[40]$} \\
& $\mathrm{Cu}(\mathrm{II})$ & 124 & 5 & $\mathrm{~L}$ & {$[41]$} \\
& $\mathrm{Cd}(\mathrm{II})$ & 84 & 5 & $\mathrm{~L}$ & \\
& $\mathrm{Ni}(\mathrm{II})$ & 67 & 5 & $\mathrm{~L}$ & \\
Adipic acid dihydrazide & $\mathrm{Cu}(\mathrm{II})$ & 200.1 & 5 & $\mathrm{~L}$ & {$[42]$} \\
\hline L= Langmuir & & & & &
\end{tabular}

Chitosan film was crosslinked using two different crosslinkers; GA and EPC for the adsorption of $\mathrm{Cu}(\mathrm{II}), \mathrm{Hg}(\mathrm{II})$ and $\mathrm{Cr}$ (II) [44]. In this work, X-ray photoelectron spectroscopy (XPS) confirmed the crosslinking of chitosan with GA and EPC occurred preferentially on hydroxyl and amino groups thus forming final structures with different functional groups. The uptake of $\mathrm{Cu}(\mathrm{II})$ and $\mathrm{Cd}(\mathrm{II})$ ions by chitosan crosslinked EPC subsequently treated with TPP was studied by Laus and Fevere [45]. The results for binary solutions showed the adsorbent has great affinity towards $\mathrm{Cu}(\mathrm{II})$ rather than $\mathrm{Cd}(\mathrm{II})$ due to a significant competition effect.

\section{Grafting of chitosan}

Grafting of chitosan allows the formation of functional derivatives by covalent binding of molecules onto chitosan backbone. This kind of modification can lead to increasing functional sides which involve in metal complexation. The adsorption capacities of grafting chitosan for the removal of different metal ions from aqueous solutions are listed in Table 2.

Table 2. Removal of different metal ions from aqueous solutions by grafted chitosan

\begin{tabular}{lccccc}
\hline Graft Copolymer & $\begin{array}{c}\text { Metal } \\
\text { Ion }\end{array}$ & $\begin{array}{c}\boldsymbol{q}_{\mathbf{m a x}} \\
\left(\mathbf{m g ~ g}^{-1} \mathbf{)}\right.\end{array}$ & $\mathbf{p H}$ & Isotherm & Reference \\
\hline Polyaniline grafted chitosan & $\mathrm{Pb}(\mathrm{II})$ & 16.1 & 6 & $\mathrm{~L}$ & {$[46]$} \\
& $\mathrm{Cd}(\mathrm{II})$ & 14.3 & 6 & $\mathrm{~L}$ & \\
Silane grafted chitosan & $\mathrm{As}(\mathrm{V})$ & 11.8 & & $\mathrm{~L}$ & {$[47]$} \\
Succinyl-grafted chitosan & $\mathrm{Zn}(\mathrm{II})$ & 1401 & 5 & $\mathrm{~T}$ & {$[48]$} \\
Poly(methacrylic acid)-grafted chitosan & $\mathrm{Cd}(\mathrm{II})$ & 146.1 & 5 & $\mathrm{~L}$ & {$[49]$} \\
Ethylacrylate grafted chitosan & $\mathrm{Pb}(\mathrm{II})$ & 613 & 6 & $\mathrm{~L}$ & \\
$N$-butylacrylate grafted chitosan & $\mathrm{Cd}(\mathrm{II})$ & 573 & 6 & $\mathrm{~L}$ & {$[50]$} \\
Amidoximated chitosan-grafted polyacrylonitrile & $\mathrm{Zn}(\mathrm{II})$ & 653 & 6 & $\mathrm{~L}$ & \\
& $\mathrm{Cr}(\mathrm{II})$ & 17.2 & 3.5 & $\mathrm{~L} / \mathrm{F}$ & {$[51]$} \\
& $\mathrm{U}(\mathrm{IV})$ & 312.1 & $\sim 7$ & $\mathrm{~L}$ & {$[52]$} \\
\hline
\end{tabular}

$\mathrm{L}=$ Langmuir, $\mathrm{T}=$ Tóth and $\mathrm{F}=$ Freundlich 
Graft copolymer of chitosan with acrylamide was prepared using gamma radiation and used for the adsorption of copper(II) and nickel(II) from aqueous solutions [53]. The adsorption of both metal ions increases with increasing $\mathrm{pH}$ and polymer concentration. At lower $\mathrm{pH}$, hydrogen ions occupy most of the adsorption sites of the adsorbent and this leads to a very low adsorption due to electrostatic repulsion. Lalita et al. was grafted chitosan with $N$ isopropylacrylamide with the presence of azoisobutrylnitrile (AIBN) as an initiator [54]. Chitosan and the graft copolymer were characterized by different techniques such as by FTIR, TGA/DTA, XRD and SEM. The graft copolymer showed good adsorption capacity towards $\mathrm{Cr}(\mathrm{VI}), \mathrm{Cu}(\mathrm{II})$ and $\mathrm{Fe}(\mathrm{II})$ ions.

Some researchers reported the enhancement of adsorption capacity after grafting due to introducing of new functional group onto chitosan chain. Galhoum et al. found that grafting of aspartic acid onto chitosan significantly increased the sorption properties for $\mathrm{Nd}$ (III) [55]. The adsorption capacity was two times higher compared to that of chitosan and GA-crosslinked chitosan. Similarly, the adsorption capacities of chitosan for several metal ions $(\mathrm{Pb}(\mathrm{II})$, $\mathrm{Hg}(\mathrm{II}), \mathrm{Cd}(\mathrm{II}), \mathrm{Ni}(\mathrm{II}), \mathrm{Mn}(\mathrm{II}), \mathrm{Co}(\mathrm{II}), \mathrm{As}(\mathrm{V})$ and $\mathrm{Se}(\mathrm{VI}))$ were increased after grafting with acrylic acid [56].

\section{Grafting of crosslinked chitosan}

Grafting copolymerization on crosslinked chitosan beads with vinyl monomers is necessary to increase the number of adsorption sites and thereby, the adsorption capacity. For example, adsorption of $\mathrm{Pb}$ (II) and $\mathrm{Cd}$ (II) was carried out by Benamer et al. on chitosan beads grafted with acrylic acid [57]. Chitosan was first crosslinked with glutaraldehyde and then grafted with monomers using ${ }^{60} \mathrm{Co}$ gamma radiation technique. The graft copolymer presented greater ability to adsorb $\mathrm{Cd}$ and $\mathrm{Pb}$ ions compared to unmodified chitosan. The adsorption capacity of the graft copolymer also increased with the increasing degree of grafting.

Our research group utilized ammonium persulfate as free radical initiator for grafting methacrylamide onto crosslinked chitosan beads. Several characterization techniques such as FTIR, TGA, SEM and ${ }^{13} \mathrm{C}$ NMR were used to confirm the successful modifications. The efficiency of the beads as adsorbent was studied to remove $\mathrm{Pb}$ (II) ions in batch experiment [58]. On the other hand, we successfully grafted $N$-vinyl-2-pyrrolidone (NVP) onto crosslinked chitosan by using the same technique (unrevealed data). The beads have shown a good adsorption capacity towards several metal ions such as $\mathrm{Pb}(\mathrm{II}), \mathrm{Cu}(\mathrm{II})$ and $\mathrm{Cd}(\mathrm{II})$. The interaction between adsorbent and $\mathrm{Cu}$ (II) ions is also proposed according to XPS analysis (Figure 2).

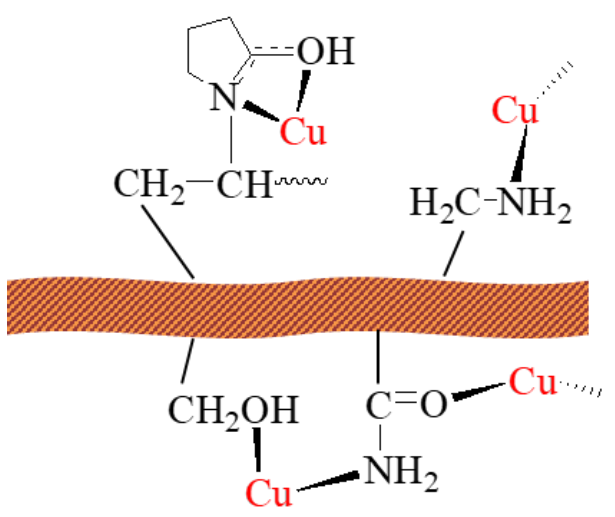

Figure 2. Possible interactions between $\mathrm{Cu}(\mathrm{II})$ ion and crosslinked chitosan-g-poly(NVP)

The effect of experimental conditions on the adsorption and desorption behavior of $\mathrm{Cd}(\mathrm{II})$ and $\mathrm{Pb}$ (II) on polyaniline grafted cross-linked chitosan beads was studied by Igberasa and Osifo [59]. The study showed that the binding of metal ions was highly dependent on factors such as $\mathrm{pH}$, adsorbent dosage, contact time, initial concentration and point of zero charge.

Novel chitosan-based adsorbent was synthesized for Fe(II) adsorption by Liu et al. from TPP and GA-crosslinked chitosan, followed by grafting with five phenolic acid derivatives (Gallic acid (GA), protocatechuic acid (PA), 


\section{Zetty Azalea et al: CHITOSAN-BASED ADSORBENTS FOR THE REMOVAL OF METAL IONS FROM AQUEOUS SOLUTIONS}

caffeic acid (CA), p-hydroxybenzoic acid (HA), vanillic acid (VA)) [60]. Results showed that the graft copolymerization occurred at amino groups (C2), hydroxyl groups (C3 and C6) of chitosan and incorporation of carboxyl groups from phenolic acids decreased in crystallinity of the polymer. In addition to the above-stated examples, several other grafting crosslinked chitosan sorbents are presented in Table 3.

Table 3. Removal of different metal ions from aqueous solutions by grafting crosslinked chitosan

\begin{tabular}{lcccccc}
\hline Chitosan Derivative & CA & $\begin{array}{l}\text { Metal } \\
\text { ion }\end{array}$ & $\begin{array}{c}\boldsymbol{q}_{\text {max }} \\
\left(\mathbf{m g ~ g}^{-1}\right)\end{array}$ & $\mathbf{p H}$ & Isotherm & Ref. \\
\hline Crosslinked chitosan-g-acrylonitrile & $\mathrm{GA}$ & $\mathrm{Cu}(\mathrm{II})$ & 230.8 & 5 & $\mathrm{~L}$ & {$[61]$} \\
& & & & & & \\
& & & & & \\
Itaconic acid grafted crosslinked chitosan beads & $\mathrm{EPC}$ & $\mathrm{Cu}(\mathrm{II})$ & 19.6 & 6 & $\mathrm{~F}$ & {$[62]$} \\
Crotonic acid grafted crosslinked chitosan beads & & & 15.9 & & $\mathrm{~F}$ & \\
Chitosan beads grafted with acrylic acid & $\mathrm{GA}$ & $\mathrm{Pb}(\mathrm{II})$ & 217.4 & 7 & $\mathrm{~L}$ & {$[63]$} \\
$\begin{array}{l}\text { Poly(acrylic acid) grafted and crosslinked chitosan } \\
\text { Poly (itaconic acid)-grafted crosslinked chitosan }\end{array}$ & $\mathrm{GA}$ & $\mathrm{GA}(\mathrm{II})$ & 224.7 & 4 & $\mathrm{~L}$ & \\
nanoadsorbent & & $\mathrm{Pb}(\mathrm{II})$ & 734.3 & 5 & $\mathrm{~L}$ & {$[64]$} \\
Poly(maleic acid)-grafted crosslinked chitosan & $\mathrm{GA}$ & $\mathrm{Hg}(\mathrm{II})$ & 870.1 & 6 & $\mathrm{~L}$ & {$[65]$} \\
& & $\mathrm{Pb}(\mathrm{II})$ & 1320 & 5 & $\mathrm{~L}$ & \\
Triethylene-tetramine grafted magnetic chitosan & $\mathrm{EPC}$ & $\mathrm{Hg}(\mathrm{II})$ & 1044 & 6 & $\mathrm{~L}$ & {$[66]$} \\
& & $\mathrm{Pb}(\mathrm{II})$ & 370.3 & 6 & $\mathrm{~L}$ & {$[67]$} \\
\hline
\end{tabular}

$\mathrm{CA}=$ crosslinking agent, $\mathrm{L}=$ Langmuir and $\mathrm{F}=$ Freundlich

\section{Conclusion and Future Perspective}

Recent years have seen increasing developments and works carried out to find alternatives in view of economic adsorbents for water treatment. Natural polymers, in particular chitosan, have high potential as sorbent in removing a wide range of contaminants, yet this material presents significant limitations which require appropriate developments. Raw chitosan (powder or flakes form) has crystalline structure, consequently limit its adsorption capacity as adsorption merely takes place on the amorphous of the crystal region. This problem is solved by converting chitosan into hydrogel beads through gel formation process. However, chitosan beads tend to dissolve in acidic medium. The stability of the beads can be enhanced by crosslinking reaction. Crosslinking agent is usually prone to react with the amine group in chitosan which known to be main chelating sites for metal ions. Therefore, grafting of functional groups onto chitosan backbone is necessary to increase selectivity and capacities. Grafting appears to be a convenient approach for improving the intrinsic properties of natural polymers or bring them with new properties.

Modifications of chitosan by crosslinking and grafting represent good alternatives for new potential adsorption system. Yet, there are still few factors that need to be considered to transfer the process to industrial scale. The influence of crosslinker content on the reaction or the properties of chitosan (i.e. crystallinity, solubility) could be investigated in future study to prepare a better adsorbent. Developing adsorbents that can remove variety of pollutants from industrial effluents is preferable. It would also be of interest to investigate other type of modified adsorbents and their capable in treating wastewater.

\section{Acknowledgement}

The authors would like to thank Universiti Teknologi Malaysia for facilitations and the Ministry of Higher Education Malaysia (MOHE) and Organization for the Prohibition of Chemical Weapon for financial supports through vote numbers Q.J130000.2509.09H84 and R.J130000.7309.4B222, respectively. 


\section{References}

1. Duruibe, J. O., Ogwuegbu, M. O. C. and Egwurugwu, J. N. (2007). Heavy metal pollution and human biotoxic effects. International Journal of Physical Sciences, 2(5): 112-118.

2. Wang, X., Guo, Y., Yang, L., Han, M., Zhao, J. and Cheng, X. (2012). Nanomaterials as sorbents to remove heavy metal ions in wastewater treatment. Environmental and Analytical Toxicology, 2(7): 1-7.

3. Okoya, A., Akinyele, A., Amuda, O. and Ofoezie, I. (2016). Chitosan-grafted carbon for the sequestration of heavy metals in aqueous solution. American Chemical Science Journal, 11 (3): 1 - 14.

4. Fu, F. and Wang, Q. (2011). Removal of heavy metal ions from wastewaters: A review. Journal of Environmental Management, 92(3): 407-418.

5. Mehdinia, A., Shegefti, S. and Shemirani, F. (2015). Removal of lead(II), copper(II) and zinc(II) ions from aqueous solutions using magnetic amine-functionalized mesoporous silica nanocomposites. Journal of the Brazilian Chemical Society, 26(11): 2249-2257.

6. O'Connell, D. W., Birkinshaw, C. and O’Dwyer, T. F. (2008) Heavy metal adsorbents prepared from the modification of cellulose: A review. Bioresource Technology, 99(15): 6709-6724.

7. Abas, S. A., Ismail, M. H. S., Lias, K. and Izhar, S. (2013). Adsorption process of heavy metals by low-cost adsorbent: A review. World Applied Sciences Journal, 28(11): 1518-1530.

8. Bhatnagar, A. and Minocha, A. K. (2006). Conventional and non-conventional adsorbents for removal of pollutants from water-a review. Indian Journal of Chemical Technology, 13(3): 203-217.

9. Wan Ngah, W. S. and Fatinathan, S. (2008). Adsorption of $\mathrm{Cu}(\mathrm{II})$ ions in aqueous solution using chitosan beads, chitosan-GLA beads and chitosan-alginate beads. Chemical Engineering Journal, 143 (1-3): 62-72.

10. Miretzky, P. and Cirelli, A. F. (2009). $\mathrm{Hg}(\mathrm{II})$ removal from water by chitosan and chitosan derivatives: A review. Journal of Hazardous Materials, 167(1-3): 10-23.

11. Vakili, M., Rafatullah, M., Salamatinia, B., Ibrahim, M. H., and Abdullah, A. Z. (2015). Elimination of reactive blue 4 from aqueous solutions using 3-aminopropyl triethoxysilane modified chitosan beads. Carbohydrate Polymers, 132: 89-96.

12. Zohuriaan-mehr, M. J. (2005). Advances in chitin and chitosan modification through graft copolymerization: A comprehensive review. Iranian Polymer Journal, 14 (3): 235-265.

13. Wang, J. and Chen, C. (2014). Chitosan-based biosorbents: Modification and application for biosorption of heavy metals and radionuclides. Bioresource Technology, 160: 129-141.

14. Wan Ngah, W. S., Teong, L. C. and Hanafiah, M. A. K. M. (2011). Adsorption of dyes and heavy metal ions by chitosan composites: A review. Carbohydrate Polymers, 83(4): 1446-1456.

15. Muzzarelli, R. A. A. (2011). Potential of chitin/chitosan-bearing materials for uranium recovery: An Interdisciplinary Review. Carbohydrate Polymers, 84(1): 54-63.

16. Zhang, L., Zeng, Y. and Cheng, Z. (2016). Removal of heavy metal ions using chitosan and modified chitosan: A review. Journal of Molecular Liquids, 214: 175-191.

17. Crini, G. and Badot, P. M. (2008). Application of chitosan, a natural amino polysaccharide, for dye removal from aqueous solutions by adsorption processes using batch studies: a review of recent literature. Progress in Polymer Science, 33: 399-447.

18. Vakili, M., Rafatullah, M., Salamatinia, B., Abdullah, A.Z., Ibrahim, M.H., Tan, K.B., Gholami, Z. and Amouzgar, P. (2014). Application of chitosan and its derivatives as adsorbents for dye removal from water and wastewater: A review. Carbohydrate Polymers, 113: 115-130.

19. Kumirska, J., Czerwicka, M., Kaczynski, Z., Bychowska, A., Brzozowski, K., Thoming, J. and Stepnowski, P. (2010) Application of spectroscopic methods for structural analysis of chitin and chitosan. Marine Drugs, 8(5): 1567-1636.

20. Bhatnagar, A. and Sillanpaa, M. (2009). Applications of chitin- and chitosan-derivatives for the detoxification of water and wastewater - a short review. Advances in Colloid and Interface Science, 152 (1-2): 26-38.

21. Azlan, K., Wan Ngah, W. S. and Lai Ken, L. (2009) Chitosan and chemically modified chitosan beads for acid dyes sorption. Journal of Environmental Sciences, 21(3): 296-302.

22. Kumirska, J., Weinhold, M. X., Thoming, J. and Stepnowski, P. (2011). Biomedical activity of chitin/chitosan based materials- influence of physicochemical properties apart from molecular weight and degree of nacetylation. Polymers, 3(4): 1875-1901.

23. Pillai, C. K. S., Paul, W. and Sharma, C.P. (2009). Chitin and chitosan polymers: Chemistry, solubility and fiber formation. Progress in Polymer Science, 34(7): 641-678. 
24. Yuan, Y., Chesnutt, B. M., Haggard, W. O. and Bumgardner, J. D. (2011). Deacetylation of chitosan: Material characterization and in vitro evaluation via albumin adorption and pre-osteoblastic cell Cultures. Materials, 4(8): 1399-1416.

25. Poon, L., Wilson, L. D. and Headley, J. V. (2014). Chitosan-glutaraldehyde copolymers and their sorption properties. Carbohydrate Polymers, 109: 92-101.

26. El-hefian, E. A., Nasef, M. M. and Yahaya, A. H. (2011). Chitosan physical forms: A short review. Australian Journal of Basic and Applied Sciences, 5(5): 670-677.

27. Adarsh, K. J. and Madhu, G. (2014). A comparative study on metal adsorption properties of different forms of chitosan. International journal of Innovative Research in Science Engineering and Technology, 3(2): 96099617.

28. Vieira, R. S. and Beppu, M. M. (2005). Mercury ion recovery using natural and crosslinked chitosan membranes. Adsorption, 11(1): 731-736.

29. Krajewska, B. (2005). Membrane-based processes performed with use of chitin/chitosan materials. Separation and Purification Technology, 41(3): 305-312.

30. Rinaudo, M. (2006). Chitin and chitosan: Properties and applications. Progress in Polymer Science, 31 (7): 603-632.

31. Mane, S., Ponrathnam, S. and Chavan, N. (2016). Effect of chemical crosslinking on properties of polymer microbeads: A review. Canadian Chemical Transactions, 3 (4): 473-485.

32. Bhattacharya, A. and Misra, B. N. (2004). Grafting: A versatile means to modify polymers: techniques, factors and applications. Progress in Polymer Science, 29(8): 767-814.

33. Cahyaningrum, S. E., Narsito, Santoso, S. J. and Agustini, R. (2010). Adsorption of $\mathrm{Mg}(\mathrm{II})$ ion from aqueous solution on chitosan beads and chitosan powder. Journal of Coastal Development, 13(3): 179-184.

34. Wan Ngah, W. S., Ab Ghani and Hoon, L. L. (2002). Comparative adsorption of Lead(11) on flake and beadtypes of chitosan. Journal of the Chinese Chemical Society, 49(4): 625-628.

35. Wu, F. C., Tseng, R. L. and Juang, R. S. (2000). Comparative adsorption of metal and dye on flake- and beadtypes of chitosans prepared from fishery wastes. Journal of Hazardous Materials, 73(1): 63-75.

36. Lee, S., Mi, F., Shen, Y. and Shyu, S. (2011). Equilibrium and kinetic studies of copper(II) ion uptake by chitosan-tripolyphosphate chelating resin. Polymer, 42(5): 1879-1892.

37. Manasi, Rajesh, V. and Rajesh, N. (2015). An indigenous halomonas BVR1 strain immobilized in crosslinked chitosan for adsorption of lead and cadmium. International Journal of Biological Macromolecules, 79: 300308.

38. Hsien, T. and Liu, Y. (2012). Desorption of cadmium from porous chitosan beads. Advancing Desalination: pp. 163-180.

39. Radwan, A. A., Alanazi, F. K. and Alsarra, I. A. (2010). Microwave irradiation-assisted synthesis of a novel crown ether crosslinked chitosan as a chelating agent for heavy metal ions. Molecules, 15(9): 6257-6268.

40. Nagireddi, S., Katiyar, V. and Uppaluri, R. (2017). Pd(II) adsorption characteristics of glutaraldehyde crosslinked chitosan copolymer resin. International Journal of Biological Macromolecules, 94(Part A): 72-84.

41. Monier, M., Ayad, D. M. and Abdel-Latif, D. A. (2012). Adsorption of $\mathrm{Cu}(\mathrm{II}), \mathrm{Cd}(\mathrm{II})$ and $\mathrm{Ni}(\mathrm{II})$ ions by crosslinked magnetic chitosan-2-aminopyridine glyoxal Schiff's base. Colloids and Surfaces B: Biointerfaces, 94: 250-258.

42. Zheng, E., Dang, Q., Liu, C., Fan, B., Yan, J., Yu, Z. and Zhang, H. (2016). Preparation and evaluation of adipic acid dihydrazide cross-linked carboxymethyl chitosan microspheres for copper ion adsorption. Colloids and Surfaces A: Physicochemical and Engineering Aspects, 502: 34-43.

43. Wan Ngah, W. S., Ab Ghani, S. and Kamari, A. (2005). Adsorption behaviour of Fe(II) and Fe(III) ions in aqueous solution on chitosan and cross-linked chitosan beads. Bioresource Technology, 96(4): 443-450.

44. Vieira, R .S., Oliveira, M. L. M., Guibal, E., Rodriguez-Castellon, E. and Beppu, M. M. (2011). Copper, mercury and chromium adsorption on natural and crosslinked chitosan films: an XPS investigation of mechanism. Colloids and Surfaces A: Physicochemical and Engineering Aspects, 374(1-3): 108-114.

45. Laus, R. and Favere, V. T. (2011). Competitive adsorption of $\mathrm{Cu}(\mathrm{II})$ and $\mathrm{Cd}(\mathrm{II})$ ions by chitosan crosslinked with epichlorohydrin-triphosphate. Bioresource Technology, 102(19): 8769-8776.

46. Karthik, R. and Meenakshi, S. (2015). Removal of $\mathrm{Pb}$ (II) and $\mathrm{Cd}$ (II) ions from aqueous solution using polyaniline grafted chitosan. Chemical Engineering Journal, 263: 168-177. 
47. Lalhmunsiama, Lalchhingpuii, Nautiyal, B. P., Tiwari, D., Choi, S. I., Kong, S. H. and Lee, S. M. (2016). Silane grafted chitosan for the efficient remediation of aquatic environment contaminated with arsenic $(\mathrm{V})$. Journal of Colloid and Interface Science, 467: 203-212.

48. Kyzas, G. Z., Siafaka, P. I., Pavlidou, E. G., Chrissafis, K. J. and Bikiaris, D. N. (2015). Synthesis and adsorption application of succinyl-grafted chitosan for the simultaneous removal of zinc and cationic dye from binary hazardous mixtures. Chemical Engineering Journal, 259: 438-448.

49. Huang, L., Yuan, S., Lv, L., Tan, G., Liang, B. and Pehkonen, S. O. (2013). Poly(methacrylic acid)-grafted chitosan microspheres via surface-initiated ATRP for enhanced removal of $\mathrm{Cd}$ (II) ions from aqueous solution. Journal of Colloid and Interface Science, 405: 171-182.

50. Maleki, A., Pajootan, E. and Hayati, B. (2015). Ethyl acrylate grafted chitosan for heavy metal removal from wastewater: Equilibrium, kinetic and thermodynamic studies. Journal of the Taiwan Institute of Chemical Engineers, 51: 127-134.

51. Santhana Krishna Kumar, A., Uday Kumar, C., Rajesh, V. and Rajesh, N. (2014). Microwave assisted preparation of n-butylacrylate grafted chitosan and its application for $\mathrm{Cr}(\mathrm{VI})$ adsorption. International Journal of Biological Macromolecules, 66: 135-143.

52. Xu, C., Wang, J., Yang, T., Chen, X., Liu, X. and Ding, X. (2015). Adsorption of uranium by amidoximated chitosan-grafted polyacrylonitrile using response surface methodology. Carbohydrate Polymers, 121: 79-85.

53. Saleh, A. S., Ibrahim, A. G., Abdelhai, F., Elsharma, E. M., Metwally, E. and Siyam, T. (2017). Preparation of poly(chitosan-acrylamide) flocculant using gamma radiation for adsorption of $\mathrm{Cu}(\mathrm{II})$ and $\mathrm{Ni}(\mathrm{II})$ ions. Radiation Physics and Chemistry, 134: 33-39.

54. Lalita, Singh, A. P. and Sharma, R. K. (2017). Synthesis and characterization of graft copolymers of chitosan with NIPAM and binary monomers for removal of $\mathrm{Cr}(\mathrm{VI}), \mathrm{Cu}(\mathrm{II})$ and $\mathrm{Fe}(\mathrm{II})$ metal ions from aqueous solutions. International Journal of Biological Macromolecules, 99: 409-426.

55. Galhoum, A. A., Hassan, K. M., Desouky, O. A., Masoud, A. M., Akashi, T., Sakai, Y. and Guibal, E. (2017). Aspartic acid grafting on cellulose and chitosan for enhanced $\mathrm{Nd}(\mathrm{III})$ sorption. Reactive and Functional Polymers, 113: 13 - 22.

56. Hong, T. T., Hai, L., Man, N. T., Tam, T. T., Thi, P. and Ha, L. (2012). Preparation of poly(acrylic acid)chitosan hydrogels by gamma irradiation for metal ions sorption. The Annual Report 2012, VINATOM: pp. 286-294.

57. Benamer, S., Mahlous, M., Tahtat, D., Nacer-Khodja, A., Arabi, M., Lounici, H. and Mameri, N. (2011). Radiation synthesis of chitosan beads grafted with acrylic acid for metal ions sorption. Radiation Physics and Chemistry, 80(12): 1391-1397.

58. Sutirman, Z. A., Sanagi, M. M., Abd Karim, K. J. and Wan Ibrahim, W. A. (2016). Preparation of methacrylamide-functionalized crosslinked chitosan by free radical polymerization for the removal of lead ions. Carbohydrate Polymers, 151: 1091-1099.

59. Igberase, E. and Osifo, P. (2015). Equilibrium, kinetic, thermodynamic and desorption studies of cadmium and lead by polyaniline grafted cross-linked chitosan beads from aqueous solution. Journal of Industrial and Engineering Chemistry, 26: 340-347.

60. Liu, J., Wu, H. T., Lu, J. Feng, Wen, X. Yuan, Kan, J. and Jin, C. Hai. (2015). Preparation and characterization of novel phenolic acid (hydroxybenzoic and hydroxycinnamic acid derivatives) grafted chitosan microspheres with enhanced adsorption properties for Fe(II). Chemical Engineering Journal, 262: 803-812.

61. Ramya, R., Sankar, P., Anbalagan, S. and Sudha, P.N. (2011). Adsorption of Cu(II) and Ni(II) ions from metal solution using crosslinked chitosan-g-acrylonitrile copolymer. International Journal of Environmental Sciences, 1(6): 1323-1338.

62. Bal, A., Özkahraman, B., Acar, I., Özyürek, M. and Güçlü, G. (2013). Study on adsorption, regeneration, and reuse of crosslinked chitosan graft copolymers for $\mathrm{Cu}(\mathrm{II})$ ion removal from aqueous solutions. Desalination and Water Treatment, 52(16-18): 3246-3255.

63. Benamer, S., Mahlous, M., Tahtat, D., Nacer-Khodja, A., Arabi, M., Lounici, H. and Mameri, N. (2011). Radiation synthesis of chitosan beads grafted with acrylic acid for metal ions sorption. Radiation Physics and Chemistry, 80(12): 1391-1397.

64. Ge, H., Hua, T. and Chen, X. (2016). Selective adsorption of lead on grafted and crosslinked chitosan nanoparticles prepared by using $\mathrm{Pb}^{2+}$ as template. Journal of Hazardous Materials, 308: 225-232. 
65. Ge, H., Hua, T. and Wang, J. (2016). Preparation and characterization of poly(itaconic acid)-grafted crosslinked chitosan nanoadsorbent for high uptake of $\mathrm{Hg}^{2+}$ and $\mathrm{Pb}^{2+}$. International Journal of Biological Macromolecules, 95: 954-961.

66. Ge, H. and Hua, T. (2016). Synthesis and characterization of poly(maleic acid)-grafted crosslinked chitosan nanomaterial with high uptake and selectivity for $\mathrm{Hg}(\mathrm{II})$ sorption. Carbohydrate Polymers, 154: 446-452.

67. Kuang, S. P., Wang, Z. Z., Liu, J. and Wu, Z. C. (2013). Preparation of triethylene-tetramine grafted magnetic chitosan for adsorption of $\mathrm{Pb}(\mathrm{II})$ ion from aqueous solutions. Journal of Hazardous Materials, 260(1): 210-219. 